\title{
Appealing to False Authority: How the Accreditation Process Encroaches on Academic Freedom
}

\author{
Brett J. Holt \\ University of Vermont, USA
}

\begin{abstract}
The research study will depict a historical discourse on Academic Freedom and the encroachments mounted by an adoption of authoritarian accreditation models in the United States. The author will explore the rationale and context behind academic freedom (Lernfreheit and Lehrfreheit) as clarified by early $19^{\text {th }}$ century academics. Compelling examples of historical infringements will be provided that illustrate dangers to the educator. A historical background for the establishment and monitoring of accrediting agencies (both institutional and programmatic) through the National Advisory Committee for Institute Quality and Integrity (U. S. Congressional Committee) as mandated through the Higher Education Act (1965) will be reported. An examination will, then, be discussed regarding the predominate accrediting body for Colleges of Education in the United States: The Council for the Accreditation of Educator Preparation (CAEP); Current examples of CAEPs encroachment on Education faculty's academic freedom will be provided. A recent alternative to CAEP will be discussed. This manuscript will conclude by making the determination that CAEP accreditation in its current format perpetuates a discourse that is antithetical to the underlying concepts of academic freedom as outlined by both the United Nations Educational, Scientific, and Cultural Organization (UNESCO) and the American Association of University Professors (AAUP). Finally, this article will challenge the reader in a discussion on how we can maintain our freedoms while working in the conventional role of having to conciliate the governmental granted authority of accreditation.
\end{abstract}

\section{Introduction}

The purpose of this research is to contextualize and operationalize academic freedom and accreditation (both institutional and programmatic) in the United States of America. And explain how the two have become incompatible. The author will begin by defining academic freedom and providing a historical context in which current tenets are founded. Definitions and examples of encroachments to academic freedom will be provided in order to orient the reader. Next, this manuscript will explore the accreditation process and offer criticism from established academics. Finally, the author will conclude by providing a vision of compatibility between the two and offer recommendations of maintaining academic freedom while undergoing program review.

\section{Academic Freedom}

According to Euben [1], over 180 scholarly organizations in the U.S.A have made institutional commitments to academic freedom by adopting policies. The consensus is that academic freedom collectively includes the freedom of inquiry, service, and both teaching and learning. Nelson [2] provides examples of both "what is" and "what is not" covered under the contextual umbrella of academic freedom. This author, in order to familiarize the reader, has included Nelson's [2] characteristics in Table 1.

The specifics regarding academic freedoms have evolved over the years to include concepts such as "due process" and "tenure" [1], it is generally accepted by the international academic community to include (broadly) the freedom to teach, the freedom to learn, the freedom to conduct inquiry and the freedom to serve. In the following sections, the author will discuss the history and importance of academic freedom.

\subsection{Historical Scope of Academic Freedom}

Holt [3] indicates that academic freedom was first established in ancient Greece. Socrates (a renowned Greek philosopher and scholar) believed his calling was to find "truth." By asking questions in his quest to find "truth," Socrates was accused, tried, and convicted of corrupting Greek society. However, one of his pupils (Plato) carried on his "truth seeking" tradition by establishing the world's first documented academy. Plato's Academy was neither attached to religion nor the 
Table1. Characteristics of Academic Freedom Nelson's [2]

\begin{tabular}{|l|l|}
\hline Academic Freedom - Allows: & Academic Freedom - Does Not: \\
\hline $\begin{array}{l}\text { Engagement in intellectual debate without fear of } \\
\text { censorship. }\end{array}$ & $\begin{array}{l}\text { Allow one to threaten, harass, intimidate, ridicule or impose } \\
\text { views on others. }\end{array}$ \\
\hline $\begin{array}{l}\text { Right to remain true to a pedagogical philosophy and } \\
\text { intellectual commitments. }\end{array}$ & Provide the right of non-mastery of content. \\
\hline $\begin{array}{l}\text { Comparison/contrasts between subject and any field of } \\
\text { human knowledge. }\end{array}$ & Prevent other academics from articulating their disposition. \\
\hline $\begin{array}{l}\text { Faculty and students the right to express views without fear } \\
\text { of sanction unless it impairs the rights of others. }\end{array}$ & $\begin{array}{l}\text { Protect from disciplinary action (although does guarantee "due } \\
\text { process"). }\end{array}$ \\
\hline $\begin{array}{l}\text { Right to draw conclusions on research that academics } \\
\text { engage. }\end{array}$ & Protect from penalties resulting from illegal activity. \\
\hline $\begin{array}{l}\text { That political, philosophical, and religious beliefs cannot be } \\
\text { imposed on the academic. }\end{array}$ & $\begin{array}{l}\text { Permit one to ignore policy or regulations (although does } \\
\text { allow for criticism). }\end{array}$ \\
\hline Right of redress if rights have been violated. & Prevent disagreement with processes and practices. \\
\hline $\begin{array}{l}\text { Protection from reprisal for disagreeing with administrative } \\
\text { policy. }\end{array}$ & $\begin{array}{l}\text { Protect the academic from various sanctions (such as denial of } \\
\text { merit raises). }\end{array}$ \\
\hline $\begin{array}{l}\text { Right to challenge alternative views (but not penalize those } \\
\text { that hold them). }\end{array}$ & Defend absenteeism of the subject matter (i.e., skipping class). \\
\hline The right to maintain academic standards. & Guarantee an unqualified lifetime appointment. \\
\hline Substantial latitude in the teaching process. & Shield from professional misconduct. \\
\hline For "due process." & Protect from investigations. \\
\hline
\end{tabular}

government which allowed it to operate independently from both. Therefore, the earliest signs of institutionalized academic freedom could be traced to Plato's Academy which established independence (sovereignty) from the external society [3].

One of the first recorded examples of academic freedom, as described by Peters [4] took place in Middle Eastern institutes of higher learning such as the Academy of Gondishapur. Ancient Persian schools began to explore academic freedoms between 500 - 900 A.D. This was a result of the Sassanid rulers welcoming Hellenic philosophers that had been banished by the Byzantine empire and Nestorian religious refugees fleeing Roman persecution. While far-eastern institutes of higher education in India and China existed earlier than some of the Persian schools, many excluded "diverse" philosophical and religious scholars and were committed to antithetical curricular discourses such as loyalty to the state and/or government. Therefore, early Persian schools became an academically appreciated unification of theological and philosophical study merged with the already established early medicinal, mathematical, martial, and astronomical disciplines [4].

The modern concepts of academic freedom, however, appear to have been established in central Europe [5]. In the early $19^{\text {th }}$, century the principles of Lehrfreiheit (translated as freedom to teach) and Lernfreiheit (translated as freedom to learn) were adopted by many European colleges and universities [6]. Most notably, a Prussian educator and academic named Wilhelm von Humboldt founded an institution in
Berlin, Germany that instituted the modern academic freedom policies that would act to contrast the predominate policies established by French universities of the time period that maintained loyalties to the emperor [6].

Dea [5] describes how through Humboldt's influence, academic freedom flourished throughout European colleges and universities. However, the rise of both fascist and communist totalitarian governments along with two world wars caused academic freedoms to be eliminated or significantly diminished throughout Europe. As a result of these troubles across the European continent through most of the $20^{\text {th }}$ century, a large portion of European universities had removed policies committed to academic freedom. However, by the second world war, American universities in the U.S. and Canada, according to Peters [4], had begun to model their academic freedom policies on that of the European universities thus preserving academic freedom.

A conference was called in Baltimore (1915) to preserve academic freedoms in the U.S. John Dewey presided over the conference and issued a letter of interest/invitation to American faculty members. He received over 650 return letters from interested faculty in organizing teachers of higher learning. Within a year, the American Association of University Professors (AAUP) was formed [7]. While, the AAUP recommended academic freedom plans to American universities in the early 1900's, it was not until 1940, during World War II, in an effort to subvert totalitarian Nazism in Europe that over 180 American universities 
and colleges adopted the academic freedom principles that currently govern most U.S. schools. The AAUP released an initial statement in 1915 and followed-up with a revised statement in 1940 addressing academic freedom. Those statements concluded that American institutions should commit to the following: 1) Teachers should be entitled to full freedoms in research and publication of results; 2) Teachers are entitled to full freedoms in introducing their subject matter; And, 3) Teachers are entitled to the same full freedoms internally and externally that all citizens are afforded including U.S. constitutional rights of free speech and expression.

The United Nations Education, Scientific, and Cultural Organization (UNESCO), at the 1993 annual conference, addressed academic freedom on behalf of the international community. Four years later, UNESCO released recommendations regarding academic freedoms for faculty members in the international community [5]. UNESCO officially issued their guidelines to the international community in 1997 regarding academic freedom. UNESCO's guiding document provides a world view on academic freedom and has defined four components: 1) freedom of teaching, 2) freedom of research, 3) freedom of intramural expression, and 4) freedom of extramural expression. UNESCO's international statement on academic freedom is similar to the 1940 statement produced by the AAUP illustrating that academics throughout the world value academic freedom and that the pursuit of academic freedom is not limited to just one region.

\subsection{Historic Importance of Academic Freedom}

Socrates, Bruno, Galilee, and Scopes might produce unpleasant images to those who know of their histories. Each of the afore mentioned academics were famously persecuted for exercising freedoms. Socrates committed suicide rather than sacrifice his academic freedoms, Bruno was executed, Galilee was forced to recant, and Scopes was found guilty and fined for violating laws in the state of TN [3]. Of the afore mentioned academics; John Scopes (Dayton, TN U.S.A.) decided, in 1925, to teach "human evolutionary theory" or "Darwinism" in classes. He was charged, convicted, and fined with violating the Butler act (a TN state law prohibiting evolutionary theory). The trial, however, was broadcast nation-wide through the use of radio making it accessible to all. This type of media broadcasting brought new found attention to academic freedom. The American Civil Liberties Union was one such organization that was attentive to the trial and continued to contest the ruling of the John Scope's trial until 1968 when a federal court overturned the ruling of 1925: Hart [8] explains that a teacher can teach theory (including evolutionary theory) and hold the students accountable to understanding theory but the teacher cannot enforce belief in non-conclusive theories. The John Scopes trial illustrates the importance for maintaining and preserving academic freedoms in more modern times.

Tenure is also considered part of the context of academic freedom. In academia, Ludlum [7] reports that numerous atrocities to academic freedom have potentially caused loss of employment amongst faculty. Ludlum [7] continues by offering the example of Professor Willard who was dismissed from Wesleyan University due to a statement he made regarding "Sunday observance" at a men's club in Hartford, CT. Dr. Nearing, likewise, was fired from the University of Pennsylvania in 1915 after nine years of service because he expressed discontent with an economic policy to several alumni. Also occurring in 1915, the University of Utah president recommended dismissal of 17 faculty members who privately expressed an unfavorable view of the Board of Regents' chair. And, Governor Bilbo of Mississippi, in what could be seen as one of the greatest atrocities against academic freedom in modern history, terminated approximately $1 / 3$ of all Mississippi public university faculty in 1930 because he found that it demonstrated to his constituents how resourceful he could be at saving state monies. Therefore, as reported by Ludlum [7], the AAUP decided to address the concepts of "due process" and "tenure." Prior to commitments to "tenure" and "due process" teachers and academics had no protections and academic freedoms could be infringed upon with threat of job loss. Without protections that offer "due process" academic freedom will continue to erode [9].

History has recorded numerous encroachments to academic freedom. Without a shared commitment to preserving those freedoms, it is likely that there will be continued encroachments. And, they may occur from unlikely places. The accreditation process will be explored to determine its encroachment on academic freedoms.

\section{Accreditation Process}

Eaton [10] stated that accreditation is intended to be a "review" process of both institutions and programs. It is widely believed that the accreditation process establishes a minimal criterion for programs and institutions to achieve in order to receive recognition.

Originally, colleges and universities in the U.S. sought validation of their programs and institutions through a process of "peer" review [10]. For example, college "A," in order to seek feedback and validation of their agriculture programs, may request faculty members from college " $\mathrm{B}$ " and college " $\mathrm{C}$ 's" agricultural programs to visit their campus, compare and contrast their curricula, conduct interviews of the 
faculty/staff/students, act as independent observer to research conducted, evaluate program objectives, etc. This was seen as "collegial" and fostered relationships between academics within the same disciplinary area of study. This type of academic review existed for over a century. However, Eaton [10] points to the 1950's as a turning point where private accreditation agencies saw an opportunity to establish relationships with the U.S. federal government. By, 1965, the Higher Education Act was signed into federal law which indicated that accreditation organizations needed to be reviewed every five years by the federal government [11]. That review process and oversight occur by a congressional committee (consisting of 18 U.S. congress members) called the National Advisory Committee for Institute Quality and Integrity (NACIQI) [10]. Currently in the U.S.A., there are over 7,000 college/universities, 20,000 programs, and 24 million students that are seeking accreditation from a federally recognized accreditation body. At the time of this writing, there exist over 19 accreditation bodies and 61 program review bodies that have been recognized by the NACIQI. Thereby, in what amounts to a "top-down" approach, the U.S. congressional committee: NACIQI recognizes accreditation organizations and programmatic review boards which in turn recognize or review colleges and their programs in a process known as accreditation [11].

\subsection{Institutional Accreditation}

The institution (college or university) receives recognition from institutional accrediting bodies. These bodies are provided oversight and recognition by the NACIQI [11]. This process is considered voluntary.

According to the Higher Education Act of 1965, institutions must meet identified criteria in order to be recognized by one of the institutional accreditors. Since its inception, however, accrediting agencies have been seeking compliance (often times on non-academic issues) rather than a focus on academic quality. And, if colleges/universities fail to comply it can affect federal funding, scholarship aid for students, etc. So, while the accreditation process is semantically referred to as a "voluntary" process, colleges and universities feel "compelled" to "voluntarily" submit their institutions to the accreditation process due to the prestige, advertisement, possible monies, and possible enrollments that accompany the process [10].

Typically, in the U.S., the institutional accreditors are established regionally. For example, this author's university undergoes accreditation through the New England Commission of Higher Education as opposed to the Southern Association of Colleges and Schools Commission on Colleges. One can visualize, based on the accrediting bodies names, how institutional accreditation in the U.S. is divided up by regions.

Accreditation at the institutional level is thought to be desired by colleges and universities. However, institutional accreditation does not involve the faculty to the extent of programmatic review.

\subsection{Programmatic Recognition}

The entire institutions undergo periodic review from institutional accreditation boards, independent programs also frequently undergo review by programmatic review boards. In the U.S., the current predominate review board for colleges of education and teacher licensure preparation programs is the Council for the Accreditation of Educator Preparation (CAEP). CAEP, therefore, conducts majority of teacher education program reviews throughout the country. As referred to earlier [10], CAEP must undergo a review themselves by the NACIQI every five years.

The American Association of Colleges of Teacher Education (AACTE) provides guidance and recommendations regarding the accreditation process of teacher preparation programs throughout the U.S. Table 2 lists the most recent guidelines that they have collectively recommended for specific teacher licensure programs [12].

Table 2. Principles for National Accreditation in Educator Preparation [12]

\begin{tabular}{|l|l|}
\hline Principle & Brief Description \\
\hline Quality Principle & Accreditation should improve the quality of education. \\
\hline Evidence Principle & Accreditation should be grounded in evidence of effectiveness. \\
\hline Consensus Principle & Accreditation should reflect a professional consensus of best practices. \\
\hline Service Principle & Accreditation should be transparent and in service to the profession and the public. \\
\hline
\end{tabular}

The principles established by AACTE are intended to guide accreditation/review organizations, such as CAEP, on teacher education programs. Note, that the principles directly place autonomy on the professional (or expert) rather than on the accrediting organization. AACTE developed and pledged commitment to these principles shortly after calling for a successful vote of "no confidence" in the afore mentioned CAEP. The dissatisfaction with CAEP by U.S. education faculty led to both the called vote and the design of the recommended principles. The vote of "no confidence" 
in CAEP taken by AACTE is a result of CAEP's encroachments on academic freedoms.

\section{Accreditation Encroachment}

Baez [13] criticizes the entire accreditation process as a form of academic reductionism:

Accreditation Processes, in the name of assessment and accountability, wind up reducing what is inherently unmeasurable - teaching and learning - to things that can be put into a language of accounting, a language that lends itself to neat little matrices. This accounting then comes to represent what we do, who we are, and how we are to be judged.

He condemns the accreditation process as the antithesis of academic freedom. Antidotally, the "topdown" controlling behavior, has been recorded amongst faculties as resembling "dictating" rather than a type of shared governance: how classes are to be taught, how students are to be assessed, how syllabi should be constructed, how programmatic websites should appear, etc. Baez [13] questions rather these types of decisions (once engaged in by faculty members) are still important to the faculty. It is speculated that new faculty are no longer socialized into a serious commitment to academic freedom, shared governance, and autonomy; and, suggested that upper-level administrators are instead socializing new faculty into the ideal of blindly following fiats beneficial to administrative needs.

Critical of sixteen years of government oversight, Eaton [10] discusses issues that occurred under both the Bush and Obama administrations in the U.S. Under the Bush administration, Eaton [10] identifies that accreditation commissions began focusing on quantifying data and comparing institutions/programs as a result of wanting to address affordability of academic institutions. However, many of these comparisons were analogous to comparing "apples" to "oranges" because overall objectives differed. Qualitative data, as a hypothetical example, obtained from a prestigious music program would have been transitioned into soft quantitative data and then used to compare "quality" with a prestigious engineering program. In this example, Julliard could have been compared to the Massachusetts Institute of Technology, even though both schools differ academically. Throughout the Bush administration, "degree mills" also began to flourish in part because in order to accommodate for rising costs of higher education, accreditation was viewed as insignificant by the consumer and the data obtained from the process was viewed skeptically thus causing a tertiary problem. After eight years of the Bush administration, Eaton [10] continued to criticize governance under the Obama administration. Under the Obama administration, accreditation became more "compliance" oriented by instituting 110 new reporting mandates that imposed regulations on general studies, student achievement, and faculty credentials. In the attempt to address the accreditation concerns caused by eight years of the Bush administration, the Obama administration could be seen as "weaponizing" the accreditation process to achieve compliance. Unfortunately, the compliance sought was not always focused on academic enrichment and often leaned more in the direction of compliance with nonacademic and behavioral issues. Eaton [10], for example, points to the consistent practice of measuring and reporting non-academic "dispositions" as a way to solicit behavioral compliance.

Ledoux, Marshall, and McHenry [9] continue the theme of academic reductionism established by Baez [13] by comparing faculty to assembly line workers:

Mastery of a body of knowledge is no longer necessary: One must simply perform specific tasks, in specific ways, in a specific order, at a specific time - not much different from an assembly line.

The authors [9] claim that the process of accreditation "objectifies" both the teacher and student thus encroaching on both lehrfreheit and lernfreheit. Further, Ledoux, Marshall, and McHenry [9] suggest that the directives from accrediting agencies encroach on academic freedoms as earlier operationalized and defined by both AAUP and UNESCO. The authors, by applying a cost/benefit analysis, question what benefits come from accreditation process? The process is indeed costly both in terms of finances and utilization of limited faculty resources; yet, the benefit for subjecting one's program through the accreditation process appears to be minimal [9].

Another opponent of the accreditation process, Wrynn [14], makes a more specific appraisal of the impairment that the accreditation process can have on any one department/program. It is commonly reported that one specific person in any department or program is ultimately responsible for the accreditation report. That report includes the collection, analysis, and reporting of data over a longitudinal period of time (often two to three years). However, that one faculty member is usually expected to fulfill their common workload responsibilities without regard to the added responsibilities occurring from accreditation. This typically leads to marginalization of one faculty member because that faculty member is contributing less to his/her established line of free inquiry, departmental service, and teaching responsibilities in order to accommodate the directives of the accrediting body. Wrynn [14] also observes that the person who is ultimately responsible for the report often does not feel 
that they had any free "choice" in the data that they collect, analyze and report. Thus, academic freedom (especially in regard to free inquiry) has been suppressed by "top-down" workload agendas.

Holt [15] indicates that the accreditation process and governance (such as the congressional NACIQI) pose a threat to academic freedom. In fact, while voluntary, it is indicated that the current trend to report Praxis exam scores (an independent norm-referenced exam used in teacher education programs) was heavily influenced by the programmatic review board: CAEP. Despite the consistent criticism of norm-referenced assessments, teacher education programs are frequently engaging their students in Praxis exams (a private organization that profits for each exam administered) in order to satisfy one of CAEP's metrics [15].

Clearly, critics of the accreditation process exist. This manuscript has identified critics at both the institutional level and the programmatic level. But what happens when the academics stop being critical of the process and begin to blindly follow the authority figures?

\section{Appealing to False Authority}

Argumentum ad veracundiam translated from its Latin root means to "appeal to authority." The meaning is that an authority figure is used to substantiate an argument. However, as Holt [16] warns, the conflation of "authority" and "expertise" are critical when considering argumentum ad verecundiam. Many academics and scientists consider an "appeal to false authority" a fallacy of argument unless all parties involved agree to the "expertise" of the authority. Award-winning astrophysics, researcher, and former academic (Cornell University), Carl Sagan, even went so far as to claim that mistrust from "authority" should be a commandment in the sciences [17].

False authority, then, is when someone in a decisionmaking role or someone who has earned the public trust is used to support an argument pertaining to content that the "authority" has developed minimal "expertise." An example of this appeal to false authority is provided by Martin [18]: Leading American zoologist and president of the University of Texas, Theo Painter, incorrectly claimed that human beings had 24 pairs of chromosomes. Painter's word was accepted as truth for almost 30 years. Human beings only have 23 pairs of chromosomes but the appeal to false authority had already been made and accepted by the lay community. For over two dozen years, even though the true answer was known through other research projects, people would not doubt Dr. Painter because he was an established authority, thereby creating an appeal to false authority.
The deeper problem was not so much that the respected authority, Dr. Painter, was incorrect (as all scientists have made a mistake), but rather the problem lies within all the academics that blindly followed his convictions and failed to challenge his claims even though conflicting evidence was found by scholars without the established reputation. An appeal to false authority had already been established. Holt [16] warns of the dangers of intentionally and unintentionally conflating "expertise" and "authority". While sometimes appealing to false authority is accidental, the appeal in the case of Dr. Painter was most likely intentional. This is why Carl Sagan expected "experts" to double-check and replicate their findings and suggested that the lay community be skeptical even if one is an established authority [17]. Firestein [19] makes a similar argument, that "experts" have a responsibility to earn the public's faith by advising the lay community to seek out authority from those with more expertise than they can currently provide.

In the context of accreditation, the NACIQI is given the authority to advise the U.S. Secretary of Education on, "establishing and enforcing the criteria for recognition of accrediting agencies or associations [11]." In other words, the members of congress that serve on this advisory committee are performing oversight of the process. A skeptic would recognize this immediately as an appeal to false authority. Since congressional members are elected, there is no guarantee that members of the U.S. congress have minimal expertise in determining the quality previously demanded by AACTE [12]. Concurrently, since there are currently 435 congressional members in the U.S., the probability that one of the 18 members represents any one person's district would be minimal (approximately 4\%). Thereby, many teacher education colleges are attempting to comply with CAEP, who in return is attempting to comply with NACIQI; And, NACIQI likely has minimal "expertise" in the discipline of Teacher Education even though they appear to have ultimate decision-making "authority."

\section{Optimistic Trend in Teacher Education}

Will [20] reports that a competitor organization, the Association for Advancing Quality in Educator Preparation (AAQEP), has been organized for Teacher Education programmatic review that stands in contrast to CAEP. Shortly after the Teacher Education Accreditation Committee (TEAC) and the National Council for the Accreditation of Teacher Education (NCATE) merged to form CAEP, a vote of "no confidence" was taken by the AACTE (an academy representing teacher education colleges). While CAEP is currently seen in the academic world as an organization that is seeking to enforce compliance, 
AAQEP is currently seen as the opposition and a return to the more collegial way of fostering relationships through review [21].

At the time of this research, Will [20] has noted that AAQEP has not yet achieved recognition by the congressional NACIQI. Therefore, seeking alternative approval from AAQEP causes distress amongst teacher education colleges that are seeking to terminate their accreditation relationship with CAEP. Ironically, even though they no longer desire their programs to be reviewed by CAEP, they still find some value in validation from the U.S. government, despite any evidence of teacher education expertise. Perhaps, Will [20] suggests that disposition will soon change? In fact, Columbia University (the oldest established Teacher Education college in the U.S.) has decided to forgo future accreditation through CAEP and instead try AAQEP [20]. Therefore, the reader could view this as an optimistic trend manifesting in the U.S.

\section{Discussion}

It was noted by the Author that since members of congress are elected (every four years) and the accrediting bodies must renew recognition through their advisory committee (NACIQI) every five years, that there is a mathematical possibility that the accreditation organizations could miss an entire committee membership within the review timeline. Secondly, 18 out of 435 equates to about four percent of current congressional members. Therefore, only about four percent of the U.S. population is being represented by the congressional members that serve on the NACIQI. Finally, it has been established that often elected officials do not meet the necessary minimal criteria to be considered within any "expertise" despite the fact that they have been granted the Authority [16].

A critical examination of the entire accreditation process beginning at the highest levels (U.S. Government) appears to be designed and implemented without any attention to the documented encroachments on the academic freedoms of the faculty [15]. This Author contends that if the accreditation process continues in its current format without challenge from the academies, it is likely that academic freedom as an established tenet may erode. As reported in this manuscript, there appears to be positive change on the horizon at least within the programmatic level for colleges of education undertaking the task of preparing teachers. The vote of "no confidence" in CAEP taken by ACCTE, the adoption of four principles to guide accrediting bodies, the formation of a competing accreditation body (AAQEP), and the transition of one of the most established colleges of education in the U.S. (Columbia University) all indicate a trend toward returning to preservation of academic freedoms while undergoing review instead of the "top-down" compliance process that has been created. The Author is motivated and encouraged by these recent transactions; However, would advise caution when placing faith in any new accreditation committee because it will eventually be held accountable to the governmental NACIQI. Therefore, the positive trend may not be sustained.

\section{Recommendations}

Given the discussion, the Author has made four recommendations below to consider:

- The Faculty professionals must become more involved on accreditation commissions. Without professional input, decisions will continue to be made in a "top-down" approach starting with elected officials that may have minimal criteria of expertise in the discipline.

- New Faculty should be socialized (perhaps in their doctoral programs) into dispositions of shared Faculty governance. Encroachments on academic freedom are likely to occur if new faculty are not committed to (or even aware of) their own freedoms.

- There should be consistent and continued monitoring and general oversight of the accreditation bodies. Through more diligent monitoring of accreditation bodies, Faculty can begin to report and defend against encroachments presented before they become precedent.

- The Faculty must engage in international dialogue so that the accreditation process (and the associated encroachments) does not become isolated. Isolation ensures that the encroaching agencies will be more successful.

\section{Conclusion}

In conclusion, this Author notes that there is evidence that the current accreditation process in the U.S. has and continues to encroach on established academic freedoms. Academic freedoms are identified priorities at a majority of U.S. colleges and universities, but they have little autonomy over their freedoms when attempting to comply with accreditation boards. Both institutional accreditation and programmatic review presents challenges to preserving academic freedoms. There may be a current trend toward positive change regarding academic freedoms and program review (at least in the context of Teacher Education programs). Finally, there are recommendations that can be instituted that could help the reader maintain academic 
freedoms while also undergoing the accreditation and review process.

\section{References}

[1] Euben D. R. (2002). 'Academic Freedom of Professors and Institutions: The Current Legal Landscape' American Association of University Professors; https://www.aaup.org/ issues /academic-freedom/professors-and-institutions (Access Date: 23 May 2021).

[2] Nelson, C. (2010). 'Defining Academic Freedom', Inside Higher Education; https://insidehighered.com/views/2010/12 21/defining-academic-freedom. (Access Date: 12 December 2021)

[3] Holt, B. J. (2021). 'An Aristotelian Appeal to Preserving Academic Freedom', In C. Shoniregun, B. Parton, and G. Akmayeva (Eds.). Education Policy and Leadership (1, 1-19). London, EN, UK: Infonomics Society.

[4] Peters, M. A. (2019). 'Ancient Centers of Higher Learning: A Bias in the Comparative History of the University?', Educational Philosophy and Theory, 51(11), pp. 1063-1072.

[5] Dea, S. (2018). 'A Brief History of Academic Freedom', University Affairs; https://www.universityaffairs.ca/opinion /dispatches-academic-freedom/a-brief-history-of-academic-fr eedom/. (Access Date: 9 October 2018).

[6] Commager, H. S. (1963). 'The University and Freedom: Lehrfreiheit and Lehrnfreiheit', The Journal of Higher Education 34(7), pp. 361-370.

[7] Ludlum, R. P. (1950). 'Academic Freedom and Tenure: A History', The Antioch Review, 10(1), pp. 3-34.

[8] Hart, A. W. (1982). The Educational Challenge of Academic Freedom in Secondary Schools, The High School Journal, 66(2), pp. 91-99.

[9] Ledoux, M. W., Marshall, T., and McHenry, N. (2010). 'The Erosion of Academic Freedom', Educational Horizons 88(4), pp. 249-256.

[10] Eaton, J. S. (2010). 'Accreditation and the Federal Future of Higher Education', American Association of University Professors; https://www.aaup.org/article/accredita tion-and-federal-future-higher-education. (Access Date: Septe -mber/ October 2021).

[11] 'National Advisory Committee on Institutional Quality and Integrity', [U.S. Education Department; Federal Registry], https://federalregister.gov/documents/2014/05/07/ 2014-10495/national-advisory-committee-on-institutional-qu ality-and-integrity-naciqi. (Access Date: 7 July 2021).

[12] American Association of Colleges of Teacher Education; Board of Directors (AACTE). High Quality Educator Preparation, http://aacte.org/resources/high-quality-educatorpreparation/. (Access Date: 2 November 2021).
[13] Baez, B. (2009). 'Faculty Forum: Accreditation fatigue', American Association of University Professors; https://www. aaup .org/article/faculty-forum-accreditation-fati gue (Access Date: May/June 2009).

[14] Wrynn, A. (2007). 'Historical Perspectives on Accreditation/Physical Education Teacher Education', Chronicle of Kinesiology and Physical Education in Higher Education, 18(2), pp. 1, 12-13.

[15] Holt, B. J., (2020). 'Identifying and Preventing Threats to Academic Freedom', International Journal for Infonomics, 13(2), pp. 2005-2012.

[16] Holt, B. J. (2019). 'Fabricated Expertise: A Risk to Educator Freedom', The International Journal for CrossDisciplinary Subjects in Education 10(4), pp. 4147-4153.

[17] Kragh, H. (2021). 'Carl Sagan: American Astronomer', Encyclopedia Britannica; https://britannica.com/biography/C arl-Sagan (Access Date: 5 November 2021).

[18] Martin, A. (2004). 'Can't Anyone Count? Counting as an Epistemic Theme in the History of Human Chromosomes', Social Studies of Science, 34(6), pp. 923-948.

[19] Firestein, S. (2012). 'Ignorance: How It Drives Science', Oxford University Press: Oxford, EN.

[20] Will, M. (2019). 'Teacher-preparation programs again have a choice of accreditors. But should they?', Education Week; https://edweek.org/leadership/teacher-preparation-pro grams-again-have-a-choice-of-accreditors-but-should-they/20 19/07. (Access Date: 24 July 2019).

[21] Loewus, L. and Sawchuck., S. (2017). Yet another group sets out to accredit teacher-prep programs', Education Week; http://edweek.org/teaching-learning/yet-another-group-sets-o ut-to-accredit-teacher-prep-programs/2017/10. (Access Date: 12 October 2017). 